\title{
Responsibilities of The Land Deed Official (PPAT) Subject Installation of Encumbrance on Credit Guarantee in Deed Granting Process Mortgage (APHT) at Bank BPR Karya Remaja Indramayu District
}

\author{
Fikrina Setyo Rini ${ }^{1}$, Agus Yuliana Indra ${ }^{2}$ and Amin Purnawan ${ }^{3}$
}

Abstract. The purpose of this study was to: 1) To determine responsibility regarding installation PPAT Encumbrance on credit guarantees in the process APHT on Bank BPR Karya Remaja Indramayu district. 2) To know the problems and solutions do just about anything regarding installation PPAT Encumbrance on credit guarantees in the process APHT in Bank BPR Karya Remaja Indramayu district. The data used in this study are primary data and analyzed with descriptive analytical method.

Based on the results of data analysis concluded that: 1) PPAT responsible for making Deed Granting Mortgage in accordance with the provisions set forth in the legislation in force, in this case the Deed Granting Mortgage shall be in accordance with the occurrence, status, and data are correct, and supported by documents in accordance with the legislation. PPAT deed made by it must be made correctly in order to create a sense of security to the parties so that all can go smoothly and there are no losers. 2) Constraints in the installation APHT Mortgage in the process is that it lacks the completeness of the file, not a guarantee in the form of certificates, as well as the difference between selfidentity in the name of National Identity Card with the name on the certificate. Therefore, the bank and PPAT should actively cooperate in completing the file completeness of the debtor and if the warranty is still in the process of making the certificate, then as a substitute for bank guarantees issued PPAT as partners covernote.

Keywords: Responsibility PPAT; Credit agreement; Installation Mortgage.

\section{Introduction}

Land Deed Official (PPAT) in carrying out its duties and responsibilities have gained legal certainty since the enactment of the National Land Agency rule No. 1 of 2006 on the Implementation of the Provisions of Government Regulation No. 37 of 1998 on the Regulation of Land Deed Official Position (Rule KBPN 1 2006) on 16 May 2006, namely in the form of guidance in a deed of land as stipulated in Article 54, which reads:

- Before the deed of the legal acts referred to in Article 2 letter a to letter g, PPAT shall check the suitability or validity of the certificate and other records at the local Land Office to explain the purpose and objectives;

- In deed referred to in paragraph (1) is not allowed PPAT contained the words "appropriate or according to the parties' formal unless backed up data;

\footnotetext{
${ }^{1}$ Students of Master of Notary Law, Faculty of Law, Universitas Islam Sultan Agung and Staff of Bank BPR Karya Remaja Indramayu, email: fikrinasetyorini69@gmail.com

2 Students of Master of Law, Faculty of Law, Universitas Islam Sultan Agung email shafa agus@yahoo.co.id

${ }^{3}$ Faculty of Law Unissula Semarang
} 
- PPAT authorities rejected the deed, which is not based on formal review of data;

- PPAT not allowed to make the deed referred to in Article 2 letter a to letter $\mathrm{g}, \mathrm{a}$ portion of parcels of land already registered or communally held land, before being measured by the Land Office and given Identification Number Parcel (hereinafter referred to as "NIB"), and ;

- In deed, PPAT shall mention NIB or number of land rights, the number of letters Tax Payable (SPPT), Tax Land and Building (PBB), the use and utilization of land in accordance with the state of the field.

The important of manufacture APHT by PPAT is a basic guarantee for the lender is to perform loading guarantee. The encumbrance of the object is of course to protect the interests of the parties and as legal certainty for the parties, as the holder of preferential rights.

The working relationship with the Notary PPAT bank is in terms of making Deed of Credit Agreement or Deed of Acknowledgment of Debt of debtors. Additionally Notary / PPAT will make a power of attorney to charge Encumbrance (hereinafter abbreviated as SKMHT) as collateral for loans that have been issued by the Bank, in this case the position of the bank as a creditor.

Based on the exposure description of the background of the above problems, the authors are keen to carry out further research to be formulated in the form of research under the title: The responsibility of PPAT in the installation of Mortgage in the process APHT Bank BPR Karya Remaja Indramayu district as well as obstacles and solutions PPAT about mounting Mortgage in credit guarantees in the process of granting the Deed of guarantee rights (APHT) in Bank BPR Karya Remaja Indramayu district.

\section{Research Methods}

The method in this research is the empirical jurisdiction, in other words is a kind of sociological and legal research can be named after the field research, including reviewing the applicable law and what happens in reality in society ${ }^{4}$. Or in other words, that a study of the actual state or the real situation that occurs in people with a view to identify and find the facts and data required, after the required data collected then leads to the identification of problems that ultimately led to the settlement of problems ${ }^{5}$.

\section{Result and Discussion}

\subsection{PPAT Responsibility In The Installation Process APHT Mortgage Bank BPR Karya Remaja Indramayu District}

PPAT responsibilities associated with obligations divided into:

- Obligations before a deed

- Article 97 paragraph 1 and 2 of the Regulation of the Minister of Agrarian Affairs / Head of National Land Agency Number 3, 1997: Before executing a deed regarding the transfer or the imposition of land rights or ownership of the apartment units, PPAT shall first examine the Land Office on the suitability of

\footnotetext{
${ }^{3}$ Bambang Waluyo, 2002, Penelitian Hukum Dalam Praktek, Sinar Grafika, Jakarta, p.15.

${ }^{5}$ Ibid., p.16
} 
land certificates or rights ownership of the apartment units are concerned with lists that exist in the local Land Office by showing the original certificate; Examination certificate referred to in paragraph 1 shall be made for each deed transfer or loading rights to parts of the land rights of the parent in the context of the marketing of the development by the company's real estate, industrial areas and the development of a type reasonably examination certificate of land holding one, unless PPAT concerned considers it necessary re certificate.

- Article 98, paragraph 1 Regulation of the State Minister of Agrarian Affairs / Head of National Land Agency Number 3, 1997

To make loading deed transfer or land rights or ownership of the apartment units and lists do not need permission to transfer of rights, except in the case as follows: Removal or imposition of land rights or ownership of the apartment units in the specified sign certificates stating that these rights may only be transferred if it has obtained permission from the authorities; Removal or imposition of use rights on state land.

- Article 100 paragraph 1 Regulation of the State Minister of Agrarian Affairs / Head of National Land Agency Number 3, 1997

PPAT refuse a deed over land rights or ownership rights to her apartment unit if accepted written notice that the land ownership or title to the apartment unit was being disputed on the person or legal entity who is party to the dispute with the accompanying document reports to the authorities, letter of claim to the trials or with regard to the provisions of Article 32 paragraph 2 of Regulation government No. 24 of 2007 concerning land registration, a letter of objection to the rights holder as well as other documents that prove the existence of the dispute ${ }^{6}$.

- The obligation in the execution of a deed

Things that must be included in the Deed Granting Mortgage in accordance with Article 11, paragraph 1 of Act No. 4 of 1996 on Mortgage:

- The name and identity of the giver and the holders of mortgage;

- Domicile of the parties;

- The clear assignment of debt or debts guaranteed;

- Value dependents;

- A clear description of the object Encumbrance;

The obligation in the execution of a deed stipulated in Article 101 Regulation of State Minister of Agrarian Affairs / Head of National Land Agency Number 3, 1997, namely:

- PPAT deed to be attended by the parties to a legal act in question or a person authorized by him with a written power of attorney in accordance with the legislation in force.

- Deed PPAT must be witnessed by at his lack of two witnesses that under the legislation in force qualified to act as a witness in a legal act which gives testimony, among others, the presence of the parties or their attorneys, the existence of documents indicated in the deed and have done the legal acts by the parties concerned.

\footnotetext{
${ }^{6}$ Boedi Harsono, Hukum Agraria Indonesia (himpunan peraturan-peraturan hukum tanah), Ed. 14, PT. Djambatan, Jakarta, p. 625-627.
} 
- PPAT shall read the deed to the parties concerned and to give an explanation about the contents and purpose of the deed and the registration procedures to be carried out subsequently in accordance with prevailing regulations ${ }^{7}$.

- PPAT obligations after a deed, among others:

After the signing of the Deed of Granting Mortgage, then the deed registered as well to the local Land Office, no later than within seven (7) working days after the signing of the Deed of Granting Mortgage and Deed Granting PPAT shall send the relevant Mortgage warkah along with the necessary support by the Land Office. Mortgage registration carried out by the Land Office to make the land book Mortgage and recorded in the land book rights over land which became the object of Encumbrance, and copy such records on land certificates in question. Date book Encumbrance land is seventh day after the date of receipt of complete documents required for registration, and if the seventh day falls on a holiday, the land book dated by the next working day. Then, as the evidence of the Mortgage, the Land Office issued the certificate Mortgage and land rights certificates stamped loading Mortgage notes.

\subsection{Constraints PPAT solutions regarding installation and Encumbrance in credit guarantees in the process of granting the Deed of Guarantee Rights (APHT) in Bank BPR Karya Remaja Indramayu district}

According to the Notary Djaka Sutana, SH that ${ }^{8}$ : In fact, there's also that accounts payable are secured by property rights not only tied with SKMHT certified. Not all accounts payable can receive property rights has not been certified as credit insurance, due to the inability of the property has not been certified used as an object of encumbrance then of course the lender will lose the right preference. Not the right preference at this creditor would pose a risk if the lender defaults.

The solution of the sociological constraints faced by the Notary in making APHT against creditors and debtors that administration of Mortgage on land that has not been certified to do with the two (2) ways: through the Power of Attorney over to Mortgage (SKMHT) and direct the administration of Mortgage Deed (APHT). The use SKMHT done because the data is not yet complete soil, both physical data and juridical data, while using APHT because the statutory provisions allow it. If the guarantee is still in the process of making the certificate, the notary provides cover note instead of credit guarantees to banks. Consideration Bank receives collateral land that has not been certified for the rule law and internal rules to allow banks and other considerations are the character and prospects of the debtor.

According to the Notary Sudiryo, $\mathrm{SH}$ that ${ }^{9}$ : Obstacles often encountered are the files were incomplete, as there is no SPPT, the latest family card, Description heir, is also different between the name on the ID card with at certificate. Besides sometimes encountered errors in writing Encumbrance value.

\footnotetext{
${ }^{7}$ Ibid., p. 628

${ }^{8}$ Results of interviews with Mr. Djaka Sutana, SH Notary PPAT on Monday, $10^{\text {th }}$ September 2018 , at $10.00-11.00$

${ }^{9}$ Results of interviews with Mr. Sudriyo, SH Notary PPAT on Thursday, $13^{\text {th }}$ September 2018, 9:00 to $10: 00$ a.m.
} 
The solution is active PPAT except notaries with the bank should also be active communication with potential customers of banks if credit has been approved by the credit committee and the banks directly contact the notary in order to complement each other shortages. Regarding the difference between the ID card with the name on the certificate, if different from the name of one or two letters can be requested depending certificate from the local village name, if more than that requested a certificate from the Department of Population and Civil Registration. If for example the citizen offspring, then there is a letter information from the court. If found incorrect in the value Mortgage writing, it must be changed by the bank itself.

\section{Closing}

\subsection{Conclution}

- Role PPAT regarding the installation of Encumbrance on credit guarantees in the process Deed Granting Mortgage is responsible for the deed he had made and the protection of the parties concerned in the deed if in the future there is a dispute between the parties, then the reference officials authorized law is sufficient the deed without the need to call back Notary PPAT since it was represented by the deed that created it. That is, the deed of Notary PPAT they must be made correctly in order to create a sense of security to the parties so that all can go smoothly and there are no losers.

- Constraints that occur include collateral to be used yet in the form of a certificate, in a sense still a Sale and Purchase Agreements, girik, letter c, kikitir. Sometimes the files are incomplete and the difference between the ID card with the name on the certificate. The solution is the bank and also notaries actively cooperate and communicate with each other.

\subsection{Suggestion}

- In general, the implementation of loading Encumbrance over land is usually preceded by the principal agreement is the agreement debts or also called credit. Before unfreeze credit agreement the bank should first consult with the Notary PPAT, in order to guarantee its prospective borrowers used later easily done for the execution process if the debtor defaults, collateral such as Sale and Purchase Agreements, girik, Letter C, Kikitir not proof finally land rights can not be burdened Mortgage.

- Banks also have to pay attention to aspects of judicial, do not just think to chase the target in lending only, while other important documents for smooth installation process also must complete Encumbrance. The validity period of APHT also worth noting, because it raises the risk of the inability Encumbrance Certificate which will result in the bank can not execute against the collateral granted by the debtor.

\section{Bibliography}

[1] AP. Perlindungan, 1996,Komentar Undang-Undang Tentang Hak Tanggungan Atas Tanah Beserta Benda-Benda yang Berkaitan Dengan Tanah dan Sejarah Terbentuknya, CV.Mandar Maju, Medan 
[2] Prof. Mr. Dr. Sudargo Gautama, 1996, Komentar Atas Undang-Undang Hak Tanggungan Baru Tahun 1996 No. 4,PT. Citra Aditya Bakti,Bandung

[3] Bambang Waluyo, 2002, Penelitian Hukum Dalam Praktek, Sinar Grafika, Jakarta

[4] Prof. Boedi Harsono, S.H., Hukum Agraria Indonesia (himpunan peraturanperaturan hukum tanah), Cet. 14, PT. Djambatan, Jakarta, h. 625-627.

[5] Results of interviews with Mr. Djaka Sutana, SH Notary PPAT on Monday, $10^{\text {th }}$ September 2018, at 10.00-11.00

[6] Results of interviews with Mr. Sudriyo, SH Notary PPAT on Thursday, $13^{\text {th }}$ September 2018, 9:00 to 10:00 a.m. 